https://doi.org/10.7250/scee.2021.0005

\title{
PROJECT MANAGEMENT IN STATE AUTHORITIES OF SUBJECTS OF THE RUSSIAN FEDERATION: DEVELOPMENT FACTORS AND RESOURCES
}

\author{
Inna MIROSHNICHENKO ${ }^{1}$, Maria TERESHINA ${ }^{2}$, Laura SHPIRO ${ }^{3}$ \\ 1,2,3 Federal State Budgetary Educational Institution of Higher Education «Kuban State \\ University», Krasnodar, Russia
}

Corresponding author e-mail: mwstepanova@mail.ru

\begin{abstract}
The article describes the Russian experience in the implementation and development of the project approach in the public administration system at the federal and regional levels. The authors characterize the two-level institutional design of the project management system in the Russian Federation in the form of strategic design and project management. At the same time, the authors note that the greatest variability and riskiness is represented by the project management subsystem, which at the level of the constituent entities of the Russian Federation has a poly-variate character. Based on the results of the empirical study, the authors have identified the factors of an institutional and subjective nature that affect the success of the implementation of project management in the constituent entities of the Russian Federation. The authors also describe a set of resources for the development of a project approach in regional authorities and local self-governments of the Russian Federation: political and administrative, socio-economic, communication-network, personnel.
\end{abstract}

Keywords: Project Management, Government Bodies, Constituent Entities of the Russian Federation, Institutional and Subjective Factors of Development.

JEL Classification: D78, H11

\section{INTRODUCTION}

The Russian Federation, as many modern states, is going through a round of administrative reforms aimed at creating new qualities of the administrative management system through the introduction of a project approach. The integration of business tools into the public administration system in the Russian Federation took place under the conditions of a number of contextual constraints:

- of socio-economic nature (isolation of Russia in the context of imposed sanctions, economic crisis and growth of socio-economic inequality of the population;

- of a political nature (the priorities declared by the political leadership of the country for achieving a high quality of life of the population in conditions of limited resources, increasing the competitiveness of the Russian Federation in the world economy through the development of innovative potential, as well as conventional and unconventional "requests" of society for the openness of government in interaction with citizens and its effectiveness).

The project approach has become an instrumental "response" to the challenges of the modern system of public administration in the Russian Federation. With its help, 
one planned to ensure the sustainable development of the country and the performance in achieving indicators in all spheres of society. Its implementation laid the foundations for a new managerial ideology, capable of changing not only the principles of making management decisions to achieve the priority goals of social development, but also the nature and style of management activities associated with the formation of an innovative culture and a qualitatively different personnel potential of civil servants of the Russian Federation.

This method is widely used in business all over the world, as well as in public administration systems in Europe, North and Latin America, Australia, and the countries of the East. Despite its versatility, the practice of introducing project management into government bodies shows that the national context determines its organizational and sociocultural "setting".

The main social problem in Russian practice is the conflict between the established administrative culture of management and the project culture inculcated "from above," the lack of synchronization between the organizational structure of the project and the organizational structure of state authorities, the intersection administration and project management functions.

Difficulties in introducing the principles of project management into the activities of state authorities and local authorities arise from the lack of flexibility and bureaucratic regulation of state structures, the orientation towards the observance of all necessary formal processes, and not towards the achievement of the final result, the lack of necessary competencies and resistance to changes by public officials at all levels.

The existing institutional model of project management in the Russian Federation includes two interrelated sets of institutional mechanisms (strategic design and project management) at the national and regional levels. The authors identified successful practices in the implementation of project management at the federal and regional levels in the Russian Federation, as well as a complex of factors (institutional structure, interdepartmental interaction, the potential for socio-economic development of the region) and resources (personnel, network, information, institutional) that affect the efficiency of implementation of project management in the constituent entities of the Russian Federation.

Scientific understanding of the Russian experience of project management in the public sector is important for understanding the factors and technologies that affect the success of the goals and objectives in the context of multi-level institutional design.

\section{THEORETICAL FOUNDATIONS AND METHODOLOGICAL APPROACHES OF THE STUDY}

The concept of new public management acts as a theoretical basis for the study. It is both a theoretical and practical response to the inability of the traditional model of public administration to respond to new economic challenges. This concept presupposes the introduction of mechanisms characteristic of the private sector into the system of public administration. There is a transformation of the hierarchically organized function of administration in the system of public administration as a way of managing the economic and social development of the country. This makes it possible to involve business and civil society institutions in solving the problems of state policy, 
to encourage original ideas for attracting resources from the non-state sector (Osborne \& Gaebler, 1992; Christensen \& Lagreid, 2001; Hood, 1991).

The concept of "new public management" substantiates the requirements for the efficiency and effectiveness of public administration. This is reflected in various forms: economic (the ratio of costs and benefits), social (the quality of public services that ensure the satisfaction of public needs) and organizational (consolidation of public sector resources to address strategic priorities of public policy).

Thanks to a set of economic and strategic tools that characterize project management, it became possible to develop the following elements of new public management: a focus on achieving results, monitoring quantitative and qualitative performance indicators based on information technology, saving budget funds, creative organizational culture, change management and innovation potential (Barnes, 2003). The project-oriented approach in public administration is a management system in which the goals of the executive bodies of state power are achieved mainly through the implementation of projects and programs (Dwivedi \& William, 2011).

The universal applicability of the project approach in the context of the principles of new public management has been demonstrated in the practice of modern states. However, scientific understanding of broad practical applicability does not have an unambiguous assessment in scientific discussions in relation to what determines the achievement of successful results in the implementation of state projects. M. Brunet notes two key factors that determine the success of project management: the formation of a viable institutional structure for project management and an understanding of government project management practices (Brunet, 2019). A number of researchers, analyzing the experience of both developed and developing countries, emphasize that the project approach is effective mainly for achieving the goals of public infrastructure development (Khan, 2019). In the latest studies, the authors pay attention not to the institutional factors that determine the success of projects in the public administration system, but to the project competencies of the specialists who implement them (Derus, 2016). G. Žurga (2018) emphasizes that subjective factors (professional competence of project managers, their personal responsibility for the results of project implementation, as well as ensuring the continuous implementation of project activities regardless of the "political agenda") are decisive in integrating project management into a tough administrative environment.

\section{RESEARCH METHODS}

Among the empirical research methods, the authors used the traditional analysis of documents characterizing the state of the project management system in government bodies at the federal and regional levels of the Russian Federation: analytical and reporting materials, official documents presented on the official websites of the President of the Russian Federation, the Government of the Russian Federation, the Scientific and Educational Center for Project Management of the Russian Academy of National Economy and Public Administration, the autonomous non-profit organization Center for Assessment and Development of Project Management "Project Olympus".

A qualitative approach (expert survey) was used by the authors to analyze the ongoing processes from the perspective of the everyday practices of public officials, on which the real results of project activities depend. Qualitative methodology was chosen by the authors to present a subjective picture - through establishing a connection 
between the actions of subjects and their intentions, needs, values, motives, as well as describing the context of the study phenomenon.

The authors also conducted an expert survey of representatives of the regional project office (Department of Project Management of Krasnodar Krai Administration), departmental project offices, project management experts who are involved in the implementation of training programs, and practical experts from business structures, providing the basis for conclusions regarding the specifics of project management implementation and its resource availability. In total, two waves of empirical research were carried out (in 2019 and 2021), a total of 40 experts were interviewed.

\section{RESULTS}

The system of project management in the state authorities of the Russian Federation has a two-tier institutional structure, which is reflected:

- in strategic design (selection of goals and priorities, formation of a portfolio of priority national projects, determination of the necessary resources for their implementation);

- in project management (preparation, implementation, monitoring and completion of projects by specialized project structures at the level of the Russian Federation and the constituent entities of the Russian Federation).

Strategic design of national development priorities is carried out at the level of the President of the Russian Federation in the relevant bylaws (Decree of the President..., 2018), which fix the substantive characteristics and target quantitative indicators of their achievement in the following areas:

- preservation of the population, health and well-being of people;

- opportunities for self-realization and development of talents;

- comfortable and safe living environment;

- decent, efficient work and successful entrepreneurship;

- digital transformation.

Decree of the President of the Russian Federation No. 474 of July 21, 2020 secures 15 national projects of the Russian Federation, including 80 federal projects, combined into three 3 groups: human capital, comfortable living environment and economic growth (National projects, n.d.). At the level of the constituent entities of the Russian Federation, regional projects are being implemented, embedded in the system of national and federal projects. Regional projects should ensure the achievement of the goals, indicators and results of the federal project, the activities of which relate to the legislatively established powers of the constituent entity of the Russian Federation, as well as to issues of local importance of municipalities located on the territory of the specified constituent entity of the Russian Federation.

The institutional subsystem of project management is the organizational structure of project management in the Russian Federation. The main body that regulates project activities at the federal level is the Presidium of the Council for Strategic Development and National Projects under the President of the Russian Federation. The functional structure of project activities in the Russian Federation includes: 
- the project office of the Government of the Russian Federation (Department of the organization of project activities of the Government of the Russian Federation);

- Ministry of Economic Development of the Russian Federation;

- departmental project offices based on federal executive authorities;

- project offices of the constituent entities of the Russian Federation (regional and departmental);

- heads, administrators, participants of national and federal projects;

- a public expert council (a collegial body formed from representatives of expert, public and business associations, organizations and groups of citizens);

- Competence Center for Design Activities (CCDA RANEPA);

- Analytical Center for the Government of the Russian Federation (ensures the performance of the functions of the project office) (Decree of the Government of the Russian Federation, 2016).

The introduction of a project management system significantly transforms the traditional administrative activities of state authorities and local government, which acquires fundamentally new characteristics and features.

Table 1. Activity components that provide a process and project approach in public administration (distinctive characteristics)

\begin{tabular}{|c|c|c|}
\hline Activity & Process activities & Project activities \\
\hline Analytics & $\begin{array}{l}\text { - assessment of the problem } \\
\text { situation ("requests" of the } \\
\text { external environment") occurs } \\
\text { at the "start" of decision- } \\
\text { making; } \\
\text { - evaluating the effectiveness of } \\
\text { the administrative processes that } \\
\text { determine the quality of the } \\
\text { "products" produced by the } \\
\text { organization; } \\
\text { - performance assessment based } \\
\text { on key performance indicators. }\end{array}$ & $\begin{array}{l}\text { - assessment of the problem situation, } \\
\text { to which the project should be } \\
\text { directed; } \\
\text { - quality assessment of the main } \\
\text { project ideas (resources and risks of } \\
\text { their implementation); } \\
\text { - evaluation of project activities } \\
\text { (efficiency of project processes); } \\
\text { - evaluation of intermediate } \\
\text { (monitoring of implementation) and } \\
\text { final results (achievement of final } \\
\text { unique results) based on qualitative } \\
\text { and quantitative criteria. }\end{array}$ \\
\hline $\begin{array}{l}\text { Organization } \\
\text { and } \\
\text { management }\end{array}$ & $\begin{array}{l}\text { - } \text { building an organizational } \\
\text { structure based on the } \\
\text { differentiation of administrative } \\
\text { processes with a rigid definition } \\
\text { of the functionality of the } \\
\text { corresponding departments; } \\
\text { - a clear system of functional one- } \\
\text { man command; } \\
\text { - regulation and standardization } \\
\text { of the activities of employees } \\
\text { implementing } \\
\text { processes; production } \\
\text { - performance assessment based } \\
\text { on key performance indicators. }\end{array}$ & $\begin{array}{l}\text { - formation of a unique project team, } \\
\text { the professional qualifications of the } \\
\text { participants of which correspond to } \\
\text { the goals and objectives of the } \\
\text { project; } \\
\text { - } \text { the project manager is endowed with } \\
\text { unique resources and powers, } \\
\text { regardless of his position; } \\
\text { - management of the team and project } \\
\text { activities as a flexible system, } \\
\text { regulation is carried out on the basis } \\
\text { of international standards of project } \\
\text { management and the project } \\
\text { passport; } \\
\text { evaluation of the effectiveness of } \\
\text { project activities based on the } \\
\text { achievement of the planned project } \\
\text { results. }\end{array}$ \\
\hline
\end{tabular}




\begin{tabular}{|c|c|c|}
\hline Communication & 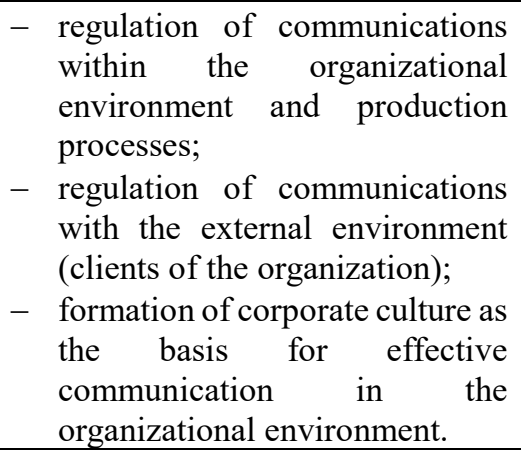 & $\begin{array}{l}\text { - development of a unified cognitive } \\
\text { scheme (language and perception) } \\
\text { among the project team members; } \\
\text { - management of communications } \\
\text { with stakeholders; } \\
\text { - formation of a project culture as the } \\
\text { basis for effective communication in } \\
\text { a project team. }\end{array}$ \\
\hline $\begin{array}{l}\text { Documentation } \\
\text { support }\end{array}$ & $\begin{array}{l}\text { - the institutional foundations of } \\
\text { the activity are the legislative } \\
\text { and regulatory framework, } \\
\text { strategic development priorities; } \\
\text { - } \text { regulation of activity processes } \\
\text { occurs on the basis of orders, } \\
\text { orders, regulations, regulations, } \\
\text { plans, road maps; } \\
\text { - the results of activities are } \\
\text { consolidated and approved by } \\
\text { reports on the achievement of } \\
\text { the strategic priorities of the } \\
\text { organization in terms of } \\
\text { indicators and indicators. }\end{array}$ & $\begin{array}{l}\text { - the institutional foundations of the } \\
\text { activity are the legislative and } \\
\text { regulatory framework, strategic } \\
\text { priorities for the development of the } \\
\text { state and territories; } \\
\text { - } \text { regulation of activity processes takes } \\
\text { place on the basis of international, } \\
\text { national standards of project activity, } \\
\text { charter or project passport, plans, } \\
\text { network schedule, decisions on } \\
\text { making adjustments; } \\
\text { - the results of activities are } \\
\text { consolidated and approved by } \\
\text { reports on the achievement of unique } \\
\text { project results in terms of criteria } \\
\text { and indicators. }\end{array}$ \\
\hline
\end{tabular}

Integration of the project and process approach promotes a new institutional design of the public administration system, including the following:

- new principles of goal-setting, focused on the final results with the solution of specific problems of the federal, regional and municipal levels, not the development of budget funds;

- formation of a multi-level public administration communications system (interdepartmental interaction within the administrative system, interaction with businesses, civil society institutions, network structures);

- human resources that meet the needs of innovative development and combine design and process tools in public decision-making (Miroshnichenko, 2019).

The main difference between project and process (operational) activities in public administration is that the second one is aimed at maintaining the stability of current tasks, while project activities are aimed at cardinal changes (Pridiba, 2018).

The authors analyzed the practice of project management in government bodies at the federal and regional levels and found that the success of the implementation and development of the project approach is due to institutional and subjective factors, mainly regional localization.

Institutional factors include:

- determination of an independent executive body of the constituent entity of the Russian Federation, responsible for the implementation of project management and implementation of projects at the regional and municipal levels; 
- inclusion in a single institutional design of project management of all state and municipal authorities of the region;

- creation of an environment for the assessment and selection of projects for implementation (expert commissions for the consideration of projects, the involvement of external experts);

- building an administration system "from the project executor to the head of the authority";

- formalization of project management (project documentation, roles, procedures, orders);

- the presence of a normatively fixed motivational policy in the field of project management at the level of the constituent entities of the Russian Federation and municipalities, focused both on the participation of employees in projects and on their successful completion (in the form of material incentives for state and municipal employees who have successfully completed the implementation of the project, as well as the assignment employees of ranks in the field of project management).

The subjective factors in the development of the project approach, which significantly transform the rigid organizational system, include:

- a high level of support for the application of the principles of project management on the part of the senior official of the constituent entity of the Russian Federation (personal interest and involvement of the governor in the implementation of national projects);

- regularly informing the management about the progress of project management implementation and project implementation;

- wide involvement of employees in project activities on the basis of material and non-material incentives and their professional retraining.

The results of an expert survey conducted by the authors showed that the specificity of the implementation of project management in the constituent entities of the Russian Federation is determined by its socio-economic and socio-political characteristics that determine the institutional design of project management and its resource provision. The effective implementation of project activities is largely determined by a set of resources, which include:

- political and administrative resources in the form of a formed and normatively fixed institutional system of project management bodies;

- socio-economic resources, conditioned by the potential of socio-economic development of the region in the form of strategic priorities enshrined in regional and municipal Strategies, their resource provision and connection with national projects;

- communication and network resources, characterized by the density of horizontal connections within the framework of interdepartmental interaction at the level of sectoral executive bodies of the constituent entities of the Russian Federation and local governments; 
- human resources (competence of participants in project activities, involvement in the activities of project teams, readiness of state and municipal employees for flexible project methods of work, for changes).

\section{CONCLUSION}

Scientific comprehension of the experience of the development of the project approach in government bodies in modern Russia has shown that its successful implementation and development is possible with a combination of a set of factors of an institutional and subjective nature. One of the necessary conditions is building the organizational architecture of project management bodies in the traditional institutional design of regional executive bodies and local self-government of the constituent entities of the Russian Federation. It is also extremely important to form human capital in the form of a community of professionals with both technical and soft skills (teamwork and communication ability), as well as the political skills necessary for project team leaders to manage and work both "inside" the project and with stakeholders.

The key resource of project management in the public sector is a new type of managers who combine administrative-process and project tools in making public decisions in a dynamically changing socio-economic and political environment. The combination of these factors and the formation of human resources contributes to the development of institutional models of project activities based on a multi-level system of public administration communications, as well as the formation and viability of "teams of changes" in regions and municipalities.

At the same time, for Russia, which has five years of experience in introducing project management into the system of public authority, there are still problematic issues related to the following:

- assessment of the effectiveness of the implementation of the project approach, both in terms of organizational structures and procedural mechanisms, and the activities of project teams;

- institutional consolidation of project-based labor functions in the professional activities of state civil and municipal employees at the level of legislation and official regulations;

- development of human resources institutions in the system of state and municipal administration, providing training in continuous education with a demanded set of competencies, the spread of value and behavioral orientations of a new culture of participation, necessary for the actualization of various forms of civic solidarity, public-private partnership.

\section{REFERENCES}

Osborne, D., \& Gaebler, T. (1992). Reinventing Government: How the Entrepreneurial Spirit Is Transforming the Public Sector. Reading, MA: Addison-Wesley.

Christensen, T., \& Lagreid, P. (2001). New Public Management - the Transformation of Ideas and Practice. Aldershot: Ashgate.

Hood, C. (1991). A Public Management for All Seasons? // Public Administration. Vol. 69.

Bevir, M., Rodes, R.A.W., (2003). Weller P. Traditions of Governance: Interpreting the Changing Role of the Public Sector// Public Administration. Vol. 81. P. 1-17. 
Barnes, M. (2003). Government and Project Management. Voropaev, V. (ed.), Project Oriented Business and Society, Moscow: IPMA - SOVNET, pp. 1-4.

Dwivedi, O.P. \& William, G. (2011). Public Administration and IASIA: Promoting Administrative Excellence Globally. Dwivedi, O.P. (ed.), Public Administration in a Global Context: IASIA at 50, Brussels: Bruylant, pp. 21-52.

Brunet, M. (2019). Governance-as-practice for major public infrastructure projects: A case of multilevel projectgoverning. International journal of project management, 37(2), 283-297.

Khan, A. (2019). Deficiencies in Project Governance: An Analysis of Infrastructure Development Program / A. Khan, M. Waris, I. Ismail, MR. Sajid, M. Ullah, F. Usman. Administrative sciences, 9(1), 9.

Gorod, A. A Systemic Approach to Complex Project Management: Integration of Command-and-Control and Network Governance / A. Gorod, L. Hallo, T. Nguyen. Systems research and behavioral science, 35(6), 811-837.

Derus, M.M. (2016). Critical Technical Competencies of Public Sector Project Managers in Developing Countries / M.M. Derus, A.R. Abdul-Aziz. Pertanika journal of social science and humanities, 24(2), 587-604.

Žurga, G. (2018). Project Management in Public Administration. TPM - Total Project Management Maturity Model. The Case of Slovenian Public Administration. Transylvanian Review of Administrative Sciences, 53, 144-159.

Decree of the President of the Russian Federation No. 204 (May 07, 2018). On national goals and strategic objectives of the development of the Russian Federation for the period up to 2024. Retrieved from: http://publication.pravo.gov.ru/Document/View/0001201805070038;

Decree of the President of the Russian Federation No. 474 (July 21, 2020). On the national development goals of the Russian Federation for the period up to 2030. Retrieved from: http://publication.pravo.gov.ru/Document/View/0001202007210012

National projects (n.d.). "Healthcare", "Education", "Demography", "Science", "Culture", "Housing and Urban Environment", "Safe and High-Quality Highways", "Small and Medium Enterprises", "International Cooperation and Export", " Digital Economy "," Labor Productivity"," Ecology "," Tourism and the Hospitality Industry "," Comprehensive Plan for the Modernization and Expansion of the Backbone Infrastructure "," Development of Nuclear Science and Technology ". Official portal of national projects of the Russian Federation. Retrieved from Национальные проекты России (хn-80aapampemcchfmo7a3c9ehj.xn--p1ai)

Decree of the Government of the Russian Federation No. 1050 (October 15, 2016). On the organization of project activities in the Government of the Russian Federation.

Miroshnichenko I.V. (2019). Personnel training for national projects: expert opinion on the Russian Investment Forum. Retrieved from: https://roscongress.org/sessions/iif-2019-podgotovka-kadrovdlya-realizatsii-natsionalnykh-proektov/expert/

Pridiba O.V. (2018). Implementation of modern technologies in the public sector: foreign countries' experience. State and municipal administration. Scholarly Scrapbook, 2, 259.

\section{AUTHORS' SHORT BIOGRAPHY}

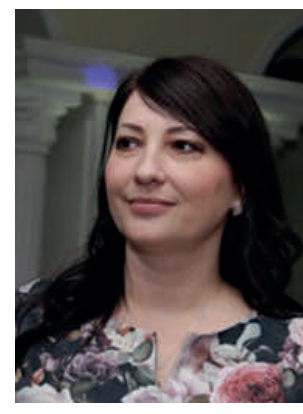

Inna Miroshnichenko (Dr sc. pol.) is a Professor, Head of the Department of Public Administration, Kuban State University, Krasnodar, Russia.

Research interests: Development Policy, Network Methodology of Political Studies, Socio-Cultural Approach in Policy Research, Political Institutions, Processes and Technology

E-mail: mirinna78@mail.ru

ORCID: http://orcid.org/0000-0002-2650-6662 


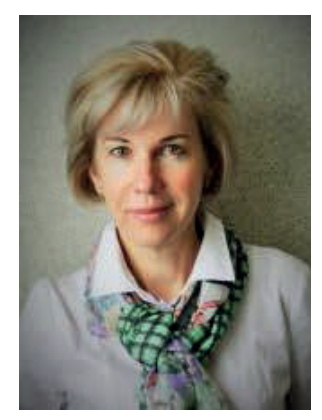

Maria Tereshina (Dr. oec.) is a Professor, Department of Public administration Kuban State University, Krasnodar, Russia

Research interests: Green and Circular Economy, Regional Sustainable Development, Urban Agglomerations Management; Regional Economy, Regional Iinnovative System.

E-mail: mwstepanova@mail.ru

ORCID: $\underline{\text { http://orcid.org/0000-0001-8982-5831 }}$

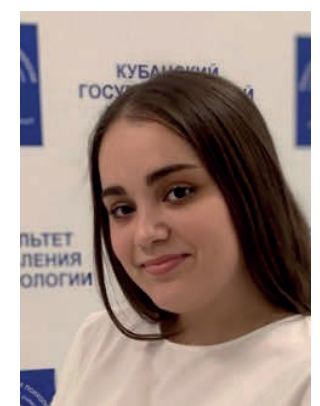

Laura Shpiro is a Master of Science, Research Officer Department of Public Administration Kuban State University, Krasnodar, Russia

Research interests: Development Policy, Project Management, Political Institutions, Processes and Technology

E-mail: laurok98@mail.ru 